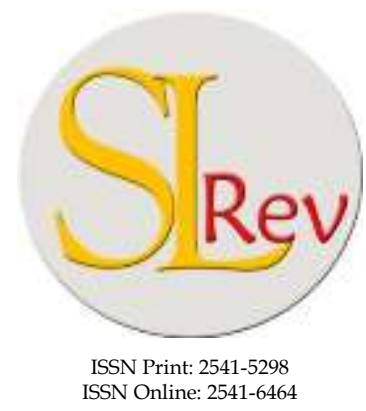

\section{The Importance of Applying the Membership Value Toward Savings and Loans Cooperatives in Indonesia}

Editorial Office: Faculty of Law, Sriwijaya University Jalan Srijaya Negara,

Palembang, South Sumatra 30139, Indonesia.

Phone: +62711-580063Fax: +62711-581179

E-mail: sriwijayalawreview@unsri.ac.id| sriwijayalawreview@gmail.com

Website: http://journal.fh.unsri.ac.id/index.php/sriwijayalawreview

\author{
Ayup Suran Ningsih, ${ }^{*}$ Duhita Driyah Suprapti, ${ }^{*}$ and Nurul Fibrianti ${ }^{*}$
}

\begin{abstract}
Cooperative Loans and Savings (KSP) is a business entity that having an essential role as an alternative capital fund which is faster and based on the Membership Principle. According to Law No 25 the Year 1992 concerning Cooperatives states that Cooperatives in Indonesia should operate under the Membership Principle. Cooperatives have social characteristics in the form of prioritizing mutual benefits and interests rather than personal interests and benefits. Thus, cooperatives must become the spearhead of the national economy by collecting and distributing funds. However, the reality, there are still numerous frauds in the process of collecting and distributing funds to raise the deposit and also the high interest and the high late charge. The problem appeared is how the actual management of cooperatives loans and savings to carry out their duties and functions. This research is also dealt with the extent of supervision, which is mandated by the law. KSP needs a proper procedural of supervision for their organization. The Financial Services Authority (OJK) is expected to work together with the Ministry of Cooperative and SMEs Office to supervise Cooperative Loans and Savings because it is found that many injustices have been fallen debtors and it is urgent to revise the law and make KSP is under OJK's supervision. The objective of this research is to examine the management of Cooperative Loans and Savings in Indonesia. The other aim of this research is to provide recomnendation and consideration for the Indonesian government to strengthen the supervision of Cooperative Loans and Savings under OJK because there is malpractice regarding the term of interest in KSP. The research method used in this article is the statute method, which is supported by an empirical juridical approach in KSP Mitra Usaha Perkasa.
\end{abstract}

Keywords: Cooperatives; Commercial Law; High Interest; Management; Membership Principle.

\section{ARTICLE HISTORY:}

\section{DOI: 10.28946/sIrev.Vol3.Iss2.235.pp225-234}

Received: Jan 24, 2019;

Reviewed: Jul 9, 2019;

Accepted: Jul 30, 2019;

Published: Jul 31, 2019.

Faculty of Law, Universitas Negeri Semarang, Semarang, Indonesia, E-mail: ayuupp@mail.unnes.ac.id

\section{INTRODUCTION}

Cooperatives are one of the concrete forms in realizing the ideals of the national economy. ${ }^{1}$ The Law No. 25 of 1992 on Cooperatives states that cooperatives, both as people economic movement and as business actors, are parts to develop a fair and prosperous

1 Consideration part of the 1992 Law No. 25 on Cooperatives. 
society based on Pancasila ${ }^{2}$ and the 1945 Constitution in national economic development managed as joint efforts by communality and economic democracy.

In the nation's economic life, cooperatives can become a means to support the progress and prosperity of the people of Indonesia. According to Nindyo Pramono, ${ }^{3}$ cooperatives as an association or economic organization consisting of people or bodies that give freedom of entry and exit as members according to existing regulations, by cooperating in a family-run business to enhance the physical well-being of its members. $^{4}$

From the explanation, Nindyo Pramono sees that cooperatives have principles and objectives, namely: firstly, cooperatives are not an organization of capital associations, but associations of people based on social, togetherness, and responsibility. Secondly, the membership of cooperatives does not recognize what coercion and by anyone, is voluntary, neutral towards flows, and religion. Thirdly, cooperatives have the aim to improve the welfare of their members by cooperating in a family manner.

As mentioned above, the cooperative adopted the orientation as stated in article 33 paragraph (1) of the 1945 Constitution which states that "The economy is structured as a joint effort based on the principle of the family." Besides that, the family principle which is an integral part of the cooperative contained in article 1 paragraph (1) of Law

2 Indonesian term for The Ideology of Republic of Indonesia, consists of five (5) principles.

3 Nindyo Pramono, Beberapa Aspek Koperasi Pada Umumnya dan Koperasi Indonesia di dalam Perkembangan, Yogyakarta: TPK Gunung Mulia, 2013, p34.

4 Ridwan Khairandy, Pokok-Pokok Hukum Dagang, Yogyakarta: UII Press, 2013, p193.
No. 25 of 1992 concerning Cooperatives. It can be interpreted that this cooperative has social characteristics to prioritize mutual benefits and interests rather than interests and personal benefits, besides that the principle of kinship emphasizes that each member of the cooperative must help each other to be jointly responsible for everything that happens in their cooperative.

Ideally, the cooperative must be the spearhead of the Indonesian economy. It is because cooperatives have their business field, namely to collect and channel funds as referred to in article 44 paragraph (1) of Law No. 25 of 1992 concerning Cooperatives, that cooperatives can raise funds and channel through savings and loan business activities for members of the cooperative concerned and other cooperatives and/or members.

However, the reality is there are often frauds and fraudulent savings collected. Of course, this is the main factor that causes the lower level of society to put their trust in cooperatives. These problems can be found where recently there was a case of the KSP Pandawa Mandiri Group.

According to the news quoted from detik.com on Tuesday, February 21, 2017, ${ }^{5}$ there were several individuals from the cooperative who had raised funds from hundreds of thousands of investors with a total loss estimated at Rp. 3 trillion. Some of the funds from the community are then loaned by them to small and medium enterprises (SMEs) traders in markets throughout Jabodetabek.

R, Mei Amelia. (2017) Polisi: KSP Pandawa Mandiri Kedok Penipuan Nuryanto Cs. Detik. [Online] Available from: https://m.detik.com/ news/berita/d-3427572/polisi-ksp-pandawamandiri-kedok-penipuan-nuryanto-cs [retrieved: $21^{\text {st }}$ February 2017]. 
While the traders who borrow the money were charged an interest of 20 percent per month. While investors are given a profit of 10 percent of the funds invested in the Pandawa Group. The thing that binds the customers the most is the considerable profit. Investors who save money immediately get 10 percent, then each month get back by 10 percent. Traders borrow money from KSP Pandawa Mandiri Group which are not members of the cooperative.

Then, it was alleged that there were bad loans from the traders so the individuals could not return profits or capital from the investors who had invested the funds. On the other hand, they also use the investors' funds to buy some assets in the form of a plot of land to private vehicles. KSP Pandawa Mandiri Group has a permit, but activities in raising funds from the community are illegal. It is because the license granted to the Pandawa KSP is a cooperative permit, not an investment permit by giving $10 \%$ interest every month.

In the example of the above events, it can be seen that there are still individuals who abuse their authority in managing the savings and loan cooperatives themselves, and supervision of the organizations becomes very important so that cooperatives can continue to be monitored so that other acts against the law do not occur again. So, the objectives and roles of the cooperative itself remain what we want by the applicable laws and regulations.

Based on the description, the authors are interested in researching the operational of savings and loan cooperatives. This article is focused on fundraising and channeling institutions as a family-based economy movement to determine the functional of KSP Mitra Usaha Perkasa Cooperative
Loans and Savings as an institution that collects and channels funds based on Membership Principle and the supervision of the KSP Mitra Usaha Perkasa.

\section{RESEARCH METHODS}

The research method used in this article is an empirical juridical approach. ${ }^{6}$ The author is retrieving the data from the laws and the regulations, applicable legal theories relating to the study in this article. ${ }^{7}$ In addition, the data in this article are also taken from direct research in the field, at KSP Mitra Usaha Perkasa. The steps of the author in writing this article are identifying the problem statements. In this step, the author finds that KSP collects higher interest than bank, collecting the literature data and other relevant data, ask permission from KSP Mitra Usaha Perkasa, doing the field research and then arrange the data and writing the article.

\section{ANALYSIS AND DISCUSSION}

\section{The Management of KSP as Funding and} Channelling Institution

The national economic developments faced by the business world, including cooperatives and small and medium enterprises, are currently high-speed and dynamic. Cooperatives are one form of business entity that is by the personality of the Indonesian nation that deserves to be developed as an essential business entity and not as a last alternative. ${ }^{8}$

Building economy needs support from the institution and norm system, both rule of law and rule of ethics that effectively and

6 Mukti Fajar, Dualisme Penelitian Hukum Normatif dan Empiris, Yogyakarta: Pustaka Pelajar, 2015, p67.

7 Waluyo Bambang, Penelitian Hukum Dalam Praktek. Jakarta: Sinar Grafika, 2001, p56.

8 Arman, D, Hutasuhut, 2001, "Manajemen Koperasi Menuju Kewirausahaan Koperasi," Journal Ilmiah Manajemen Bisnis, 1 (1), pp29-39. 
efficiently manage and direct to the distribution of clean and smooth prosperity. Thus, economic system and economic policy must be obedient to the Five Principles (Pancasila) and the 1945 Constitution of the Republic of Indonesia as the basis of the constitutional law, ethics and as a foundation for the economic system and national economic policy. Accordingly, the constitution of Republic of Indonesia Year 1945 is not the same as in the other countries such as the United States constitution managing the economic principles and economic norms in chapter XIV on the national economy and social prosperity. Therefore, the 1945 Constitution of the Republic of Indonesia is as the politic constitution, economy constitution, as well as the social constitution. ${ }^{9}$

Cooperatives are unions which aim to fulfill the welfare of its members. Cooperatives are financial business organizations that have an essential role in the economy of the middle to lower classes. It is crucial because one of the functions of cooperatives is to be a fast alternative to capital and based on the principle of family. ${ }^{10}$

It is very helpful because business capital loans to banks are usually more difficult to approve. Even if the application is approved, the time of submission until the disbursement of funds can take monthly time.

Therefore, the existence of cooperatives can accelerate the economy of microenterprises while at the same time hindering the practice of loan sharks, which is very

9 Jimly Asshiddiqie, Konstitusi Ekonomi, Jakarta: PT. Kompas Media Nusantara, 2016, p35.

10 Mochamad Zain Adib, Politik Hukum Koperasi di Indonesia (Tinjauan Yuridis Historis Pengaturan Perkoperasian di Indonesia), Yogyakarta: Master of Law, Faculty of Law, Universitas Gadjah Mada, 2014, pp67-74. burdensome for people who require venture capital.

Financial institutions have a significant role for the community, not just banks, savings, and loan cooperatives also help the community to manage and fund assistance to the community.

It can be said that savings and loan cooperatives are institutions that move from and to the people.

The fact that KSP is also a company that makes and profit-oriented takes effect of their policy. The only profit that they can make is from the interest that KSP collects from their member. It can be the cause of unfair competition between the other finance company. ${ }^{11}$

That is, cooperatives run through community funds in the form of managing funds for business capital. Furthermore, the funds can be used by the community to borrow it.

From these processes, the rules for savings and loan cooperatives implemented are not as strict as banks. The cooperative has the role of providing loan funds for people who have economies below average and as venture capital. In its service, cooperatives also do not prioritize service to members, but also the wider community.

The essence of the cooperative is "cooperation," but not all cooperation can be said to be a cooperative. It means that the meaning of cooperation varies, depending on where we see it. When viewed from the legal aspect, cooperative is a legal entity that has certain obligations and rights. According to the view of anthropology, cooperation is

11 Ayup Suran Ningsih, "Implikasi Undang-Undang Nomor 5 Tahun 1999 tentang Larangan Praktek Monopoli dan Persaingan Usaha Tidak Sehat pada Pelaku Usaha Mikro Kecil dan Menengah (UMKM)," Jurnal Penelitian Hukum De Jure, 19 (2), pp207-215. 
one form of activity carried out to maintain the survival of a society.

Whereas, in social sciences, cooperation is an organization which is one of the elements is the dynamics of social life. Cooperatives which contain the meaning of cooperation are cooperatives as modern economic institutions that have goals, management systems, orderly organization and rules, and have principles and principles. ${ }^{12}$

Cooperatives are associations of people who prioritize service to the economic needs of their members as well as citizens.

Savings and loan cooperatives or often referred to as credit cooperatives are financial institutions other than banks that are managed and run to provide capital loan assistance and provide low-interest rates. The initial goal of savings and loan cooperatives is to provide financial solutions only for cooperative members, but along with the development of needs in the community, cooperatives contribute to helping for small business needs and withdrawing funds from the general public. ${ }^{13}$

Based on Article 4 The 1992 Law No 25 concerning Cooperatives, the aims of cooperatives shall be:

"Function and Roles of Cooperatives shall be: a) to develop and improve the economic potentials and capability of its members and society in general to increase its economic and social wealth; $b$ ) to take parts actively in the efforts to heighten the life quality of human being and society; c) to strengthen people's economic as strong basis and defense of national economy

12 Akhmad Junaidi and Muhammad Joni, "Kapasitas Badan Hukum Koperasi Dalam Melakukan Kegiatan Koperasi Telaah YuridisKonstitusional," Infokop, 24 (2), pp56-64.

13 Nanik Susan, 2014, "Sistem Informasi Simpan Pinjam Badan Keswadayaan Masyarakat Studi Kasus BKM Sarana Makmur," Jurnal Simetris, 5 (1), pp93-104. using cooperatives as the central pillar; $d)$ to try to create and develop a national economy that is joint efforts based on familial principles and economic democracy."

Banks and cooperatives have several functions in common, such as providing capital assistance and attracting funds from the community in the form of savings or deposits.

Even though it has the same function, cooperatives have several advantages that make it more attractive than banks.

\section{KSP Mitra Usaha Perkasa}

KSP Mitra Usaha Perkasa is a legal entity in private cooperative. It was in Sebandaran Street, Semarang City. KSP Mitra Usaha Perkasa provides a loan with interest starting from $1,8 \%$ and up, with the collateral of Freehold Title. One of the differences between KSP Mitra Usaha Perkasa with others cooperative that the author found in research is people can get the loan without being a member of the cooperative. It is wrongdoing which cooperative did because KSP is not a finance company. There is a strict difference between the finance company and cooperative based on their regulation.

Law should follow the dynamics of development and the needs of society to create order and certainty of the law with justice. ${ }^{14}$ We know that to fulfill their needs, they got some loans, but that's condition shouldn't be used for cooperative to take high profit for their cooperative by applying high interest and interest penalty.

Based on Research in KSP Mitra Usaha Perkasa in Semarang City, the role of savings and loan cooperatives in responding to

14 Erma Defiana Putriyanti, "Legal Status of Credit Bank Guarantee in Indonesia's Legal Guarantee," Sriwijaya Law Review, 1(2), p140. 
community needs that cannot be obtained compared to other financial institutions:

\section{Providing business capital}

Cooperative in providing convenience in providing capital. To achieve capital loan funds from cooperatives can be without various troublesome conditions. For small businesses or businesses that are still running (micro), cooperatives will provide convenience in the capital. People who went to KSP are those who got rejected from Bank or other finance company, but they got the painful consequence with the high interest. KSP provide their loans with higher interest than Bank.

\section{Improve social welfare}

One function of cooperatives is to channel credit funds to members and the community. Where these funds can be used for productive business activities, such as for opening a business or expanding business activities. By supporting this productive activity, it is expected that it can create a movement that results in an increase in economic income in the community.

So, in the end, it will achieve all the shared desires in realizing social welfare that is equitable and reduces poverty in the community. It is a positive impact on the existence of economic income equalization. The more productive cooperative activities will provide more welfare for the members of the cooperative, namely by sharing the remaining business income (SHU) at the end of each year. It is another benefit that will be felt by all elements of the cooperative with the circulation of funds, which increases the economy of members and the community.

\section{Blocking the practice of loan sharks}

The need for expansion of business activities, it will encourage entrepreneurs to seek additional business capital as quickly as possible. Constraints in applying for a capital loan to a bank, which requires a lot of requirements and feasibility assessment, plus high interest, which can later add to the financial burden of business results. The right solution is to apply for a loan to a cooperative because the process is fast even without conditions. Another advantage is the interest offered is much smaller than the Bank so that it will provide convenience and comfort, especially for small and medium businesses. With the existence of cooperatives during the community will offer more accessible financial solutions.

However, the fact is that until now, there are still many practices of moneylenders that always occur in the community. The problem when the population is not adequately educated about the existence of cooperatives is when these capital needs become very urgent then a quick solution is to borrow from moneylenders, moneylenders generally impose very high-interest rates, so this practice has more disadvantages than the benefits. Introducing cooperatives to the community and whatever cooperative services that can be utilized by the community will provide education that there are safer and more humane solutions so that the practice of loan sharks is no longer valid in the community.

\section{Accelerating economic growth}

ASEAN countries have now opened a free market, better known as the MEA (ASEAN Economic Community ${ }^{15}$. With the enactment of the MEA, this is a strategic medium for Indonesia to accelerate national economic growth. One way to deal with this free

\footnotetext{
15 http://www.depkop.go.id/masyarakat-ekonomiasean [retrieved: July 17, 2019].
} 
market is to offer quality and creative products from the domestic SME industry. The government must encourage the creation of new SMEs both on a small, medium scale, up to the top, all must be involved in expanding the international market. The existence of cooperatives is the right step in supporting the growth of SMEs sectors, especially for small and medium scale. With the demand to produce new and quality products, of course, for small and medium sector SMEs, the main obstacle is capital. Herein lies the role of cooperatives in assisting SMEs, namely in terms of capital, so that the impact can accelerate national economic growth.

The things conveyed by the author above are what should be done by the Cooperative which is the goal of the establishment of the cooperative, but nowadays the presence of the Savings and Loan Cooperative is far from what is expected. Cooperatives whose business units are engaged in savings and loans to have very high-interest rates charged to debtors. This is known after doing research; it was immediately known that this KSP took loan funds from the Bank, which then the funds were given to debtors. So, if the debtor borrows money from the cooperative, the debtor will be charged high interest (cooperative interest to the bank and the debtor's interest to the cooperative) of course this is very far from the goal of establishing a cooperative by Indonesian Cooperative Funding Father $\mathrm{Mu}-$ hammad Hatta.

\section{Supervision of the Savings and Loan Co- operatives of KSP Mitra Usaha Perkasa}

A legal entity such as a cooperative indeed requires a system of internal controls that are used to assess the performance of the bodies within the cooperative. There are several methods used in the supervision process. Supervision can be divided into two, namely qualitative supervision methods and quantitative supervision methods.

Qualitative supervision is carried out by managers to maintain overall organizational performance, employee attitudes, and performance. Quantitative monitoring methods are carried out using data, usually used to monitor the quantity and quality of products. There are several methods commonly used to conduct quantitative supervision, including using the budget, holding auditing, break-even analysis, ratio analysis, and so on.

In supervision, there are several types of control. The supervisory function can be divided into three types, based on the focus of supervisory activities, including ${ }^{16}$

\section{Preliminary control}

Preliminary surveillance procedures include all managerial efforts to increase the likelihood that actual results will be close to the results compared to the planned results. From this perspective, policies are guidelines for future actions. However, even so, it is essential to distinguish the act of compiling policies and measures to implement them.

Formulating policies is included in the planning function while the act of implementing policy is part of the supervisory role. Preliminary supervision includes:

a. Initial control of human resources.

b. Preliminary supervision of materials.

c. Supervision of preliminary capital, preliminary oversight of financial resources

16 Daniel Asnur and Teuku Syarif, 2014, "Realita Dan Prospek Pengembangan Koperasi Simpan Pinjam," Infokop, 24 (1), pp85-93. 


\section{Concurrent control}

Concurrent control consists mainly of the actions of the supervisors who direct the work of their subordinates. The Board of Directors deals with the efforts of managers as they strive to:

a. Teach their subordinates about how to apply the appropriate methods and procedures.

b. Keep an eye on their work so that work is carried out correctly.

c. The process of giving direction not only covers how the instructions are communicated but also includes the attitudes of those who give submission.

\section{Feed Back Control (feedback control)}

The distinctive feature of the methods of monitoring feedback is that it focuses on historical results, as a basis for correcting future actions. The number of feedback control methods that are mostly carried out are Financial Statement Analysis, Standard Cost Analysis, Quality Control, and Employee Performance Evaluation.

The factor of implementation of a repressive legal system, all are governed and oppressed by policies of the government. Law and regulation that rules cooperative to maintain power, by controlling the cooperative with the rules of cooperative, so that cooperative does not have rights to fight for economic and social aspirations. Economic globalization factor also affect the indistinctness of concept of cooperative that is based on independent kinship, change the view of the Government on arrangement of cooperative to be more directed to the soul of the capitalist, member is regulated to be a spectator, not a player who only waits for the profits at the end of the year. The factor of policy of assistance distribution, either in the form of social assistance or grant to community groups such as fishermen, farmers, and plantation and business groups of other societies require the association has a legal entity of cooperative. The establishment of cooperative is only for the pursuit of government assistance and eliminates the identity of an actual cooperative. ${ }^{17}$

Based on the description above, it is essential for KSP's founder to supervise their KSP with such a procedure like mention above. Based on research, KSP Mitra Usaha Perkasa does not apply supervision to KSP as explained above.

Supervision of the organization takes an important part. It is a part of good corporate governance. Good Corporate Governance can help to prevent corporate scandals, fraud, and potential civil and criminal liability of companies. Good Corporate Governance enhances the image and reputation of a company and makes it more attractive to investors, suppliers, customers, and other stakeholders of the company. There is evidence from many types of research that good corporate governance produces a direct economic benefit to the company, making it more profitable and competitive ${ }^{18}$ Based on that fact, it is urgent to include KSP in supervision under OJK, because OJK has an excellent and structured procedural to provide Good Corporate Governance for KSP.

The author asks the Director of KSP Mitra Usaha Perkasa, she said: "KSP Mitra Usaha Perkasa has their internal and independent auditor to audit their operational

17 Abdul Haris, Iwan Permadi, Sihabudin, Suhariningsih, "Cooperative Business Enterprise in Indonesia Based on Law Politics Perspective," Journal of Law, Policy and Globalization, 64, pp110-118.

18 Igor Todorovic, 2013, "Impact of Corporate Governance on Performance of Companies," Montenegrin Journal of Economics, 9 (2), p47. 
once in a year." It is insufficient to complete supervision.

The Official Cooperatives and Micro Enterprise Semarang did not check the management of KSP Mitra Usaha Perkasa regularly, like what OJK did. The Supervision Unit of The Official Cooperatives and Micro Enterprise Semarang will do the supervising when there is a report regarding the cooperative.

It was such an awful and terrible fact. Because of that, KSP Mitra Usaha Perkasa was very persistent in operating their business and took high-interest and high late charge from their member.

It was so far from justice and the aims of Cooperative, like The Funding Father of Cooperative, Muhammad Hatta said Cooperative should help society, not burdensome. Based on this fact, the author noted that KSP Mitra Usaha Perkasa is the same with loan sharks.

\section{CONCLUSION}

The membership principle value must be fully implemented by cooperatives that have played an active role in providing business capital for members and the surrounding community.

Cooperative as a legal entity and also a profit-oriented company should be a balance in take their policy regarding interest and late charge. Based on Cooperatives Law, Cooperative can get their fund by loans from bigger bank but that's not the reason to charge high interest and high late charge from debtors.

The process of supervision carried out by cooperatives in the implementation; there is internal supervision in the operational implementation of cooperatives carried out by qualitative and quantitative methods and ex- ternal supervision. The Financial Services Authority (OJK) is expected to work together with the Ministry of Cooperative and SME Office to supervise Cooperative Loans and Savings because it is found that many injustices have been fallen debtors and it is urgent to revise the law and make KSP is under OJK for supervision.

\section{REFERENCES}

Books

Asshiddiqie, Jimly. 2016. Konstitusi Ekonomi. Jakarta: PT. Kompas Media Nusantara.

Adib, Mochamad Zain Adib. 2014. Politik Hukum Koperasi di Indonesia (Tinjauan Yuridis Historis Pengaturan Perkoperasian di Indonesia). Yogyakarta: Thesis of Master of Law, Faculty of Law, Universitas Gadjah Mada.

Bambang, Waluyo. 2001. Penelitian Hukum Dalam Praktek. Jakarta: Sinar Grafika.

Fajar, Mukti. 2015. Dualisme Penelitian Hukum Normatif dan Empiris. Yogyakarta: Pustaka Pelajar.

Khairandy, Ridwan. 2013. Pokok-Pokok Hukum Dagang. Yogyakarta: UII Pres.

Pramono, Nindyo. 2013. Beberapa Aspek Koperasi Pada Umumnya dan Koperasi Indonesia di dalam Perkembangan. Yogyakarta: TPK Gunung Mulia.

\section{Journals}

Arman, D, Hutasuhut. 2001. "Manajemen Koperasi Menuju Kewirausahaan Koperasi." Jurnal Ilmiah Manajemen Bisnis. 1 (1).

Asnur, Daniel, Teuku Syarif. 2014. "Realita Dan Prospek Pengembangan Koperasi Simpan Pinjam." Infokop. 24 (1).

Haris, Abdul, Iwan Permadi, Suhariningsih Sihabudin. 2017. "Cooperative Business Enterprise in Indonesia Based on Law Politics Perspective." Journal of Law, Policy and Globalization, 64 (1). 
Junaidi, Akhmad, \& Muhammad Joni. 2014. "Kapasitas Badan Hukum Koperasi Dalam Melakukan Kegiatan Koperasi. Telaah Yuridis-Konstitusional.” Infokop. 24 (2).

Ningsih, A. 2019. "Implikasi UndangUndang Nomor 5 Tahun 1999 tentang Larangan Praktek Monopoli dan Persaingan Usaha Tidak Sehat pada Pelaku Usaha Mikro Kecil dan Menengah (UMKM)." Jurnal Penelitian Hukum De Jure, 19 (2).

Putriyanti, E. D. "Legal Status of Credit Bank Guarantee in Indonesia's Legal Guarantee.” Sriwijaya Law Review. 1 (2).

Susanti, Nanik. 2014. "Sistem Informasi Simpan Pinjam Badan Keswadayaan Masyarakat Studi Kasus BKM Sarana Makmur.” Jurnal Simetris. 5 (1).
Todorovic, I. 2013. "Impact of Corporate Governance on Performance of Companies." Montenegrin Journal of Economics. 9 (2).

\section{World Wide Web}

Detik.com. 2017. Polisi: KSP Pandawa Mandiri Kedok Penipuan Nuryanto Cs. Available from: https://m.detik.com/news/ berita/d-3427572/polisi-ksp-pandawamandiri-kedok-penipuan-nuryanto-cs. [retrieved: $21^{\text {st }}$ February 2017]

Depkop.go.id

http://www.depkop.go.id/masyarakatekonomi-asean [retrieved: Wednesday, 17th July 2019, 09:20 WIB]

\section{Regulation}

The 1992 Law No. 25 on Cooperatives. 